\title{
А.Н. Мунайтпасова $\mathbb{D}$ *, I.E. Дапен \\ Әл-Фараби атындағы Қазақ ұлттық университеті, Қазақстан, Алматы қ. \\ *e-mail: dapenova.inkar@mail.ru \\ ҚАЗАҚСТАНААҒЫ СТРАТОСФЕРААЫҚ, ОЗОННЫН TAPAАУ EPEKШEАIKTEPI
}

Озонды бақылау және оның құрамына мониторинг жүргізу өте маңызды, өйткені олар әлем халқына жер бетіндегі өмірді қорғауға бағытталған саясат саласында негізделген шешімдер мен шаралар қабылдауға негіз береді. Озон қабатының жұқаруы табиғатқа, адам денсаулығына зиян келтіретіндіктен, Қазақстан территориясындағы стратосфералық озонның кеңістіктік-уақыттық динамикасын зерттеу маңыздылығын жоғалтпайды.

Озон және ультракүлгін сәуле жөніндегі дүниежүзілік деректер орталығы мен Вайоминг университетінің бақылаулары нәтижесінде алынған аэрологиялық мәліметтер негізінде Қазақстанда озонға бақылау жүргізілетін станциялар бойынша озонның жалпы мөлшері мен оның басқа да метеорологиялық параметрлермен (20 км биіктіктен жоғары ауа температурасы, салыстырмалы ылғалдылық және жел жылдамдығы) байланысы зерттелді және олардың арасындағы корреляциялық байланыс есептелді.

Бақылау қатарларын корреляциялық талдау көмегімен шамалар арасындағы қатынастар зерттелді, олардың өзара әрекеттесуінің мүмкін механизмдері туралы гипотезалар айты^ды және зерттеу әдісі ретінде статистикалық өңдеу әдісі қолданы^ды. Қарастырылған сипаттамалардың орташа жылдық жүрісі келтірілді.

Нәтижесінде қарастырылған метеорологиялық параметрлердің әрқайсысы озонның концентрациясына әсер ететіні, әсіресе, ауа температурасының өзгерістерімен тығыз байланыста екені анықта^ды. Стратосфераның қатты қызуы әсерінен ауа температурасы мен ОЖҚ арасындағы оң байланыс анықта^ды, ал ол қалыпты жағдайда теріс байланысқа ие.

Түйін сөздер: озонның жалпы құрамы, температура, салыстырмалы ылғалдылық, оң және теріс корреляция.

\author{
A.N. Munaitpasova*, I.E. Dapen \\ Al-Farabi Kazakh National University, Kazakhstan, Almaty \\ *e-mail: dapenova.inkar@mail.ru
}

Features of stratospheric ozone distribution in Kazakhstan

Ozone control and monitoring are very important because they provide the world's population with a basis for making informed decisions and policies to protect life on earth. Since the thinning of the ozone layer is harmful to nature and human health, the study of the spatial and temporal dynamics of stratospheric ozone on the territory of Kazakhstan does not lose its significance.

Based on aerological data obtained from observations of the world ozone and ultraviolet data center and the University of Wyoming, the total amount of ozone and its relationship with other meteorological parameters (air temperature above $20 \mathrm{~km}$ altitude, relative humidity and wind speed) at stations where ozone observations are carried out in Kazakhstan were investigated and the correlation between them was calculated.

Correlation analysis of control series was used to study the relationships between values, hypotheses were made about possible mechanisms of their interaction, and the method of statistical processing was used as a research method. The average annual moves of the considered characteristics are given.

As a result, it was found that each of the considered meteorological parameters affects the ozone concentration, especially in close connection with changes in air temperature. Under the influence of strong heating of the stratosphere, a positive relationship between the air temperature and the total ozone was revealed, while under normal conditions it has a negative relationship.

Key words: total ozone content, temperature, relative humidity, positive and negative correlation. 


\title{
А.Н. Мунайтпасова*, I.Е. Аапен \\ Казахский национальный университет имени аль-Фараби, Казахстан, г. Алматы \\ *e-mail: dapenova.inkar@mail.ru \\ Особенности распределения стратосферного озона в Казахстане
}

\begin{abstract}
Контроль озона и мониторинг его содержания очень важны, поскольку они Аают населению мира основу Аля принятия обоснованных решений и мер в области политики, направленной на защиту жизни на земле. Поскольку истончение озонового слоя наносит вреА природе, зАоровью человека, изучение пространственно-временной динамики стратосферного озона на территории Казахстана не теряет своей значимости.

На основании аэрологических данных, полученных в результате наблюдений Всемирного центра данных по озону и ультрафиолетовому излучению и Университета Вайоминга, исследовано общее количество озона и его связь с Аругими метеорологическими параметрами (температура воздуха выше высоты 20 км, относительная влажность и скорость ветра) по станциям, на которых проводятся наблюдения за озоном в Казахстане, и вычислена корреляционная связь между ними.

С помощью корреляционного анализа контрольных рядов изучались отношения межАу величинами, высказывались гипотезы о возможных механизмах их взаимодействия, в качестве метода исследования использовался метод статистической обработки. Приведены среднегодовые ходы рассматриваемых характеристик.

В результате было установлено, что каждый из рассмотренных метеорологических параметров влияет на концентрацию озона, особенно в тесной связи с изменениями температуры воздуха. Под Аействием сильного нагрева стратосферы выявлена положительная связь между температурой воздуха и ОСО, при этом она в нормальных условиях имеет отрицательную связь.

Ключевые слова: общее содержание озона, температура, относительная влажность, положительная и отрицательная корреляция.
\end{abstract}

\section{Kipicne}

Озон - жер атмосферасындағы оттегінің тіршілік формасы. Атмосфераның температурасы мен газ құрамының, сондай-ақ ондағы аэрозольдардың құрамының аздаған өзгерістері озон мөлшерінің өзгеруіне әкеледі. Озон өте аз болғанымен, ол жерде өмір сүруде өте маңызды рөл атқарады, өйткені күннен шыққан ультракүлгін сәулесінің қатты бөлігін сіңіреді (толқын ұзындығы 280-нен 315 нм - ультракүлгін сәулелену деп аталатын), осылайша тірі организмдер мен өсімдіктерді қорғайды. Атмосферадағы озонның мөлшерін әртүрлі сипаттауға болады. Озонның мөлшерін белгілі бір биіктікке анықтауға болады. Дегенмен де, көптеген жұмыстар үшін озонның биіктік бойынша таралу мөлшерін білу маңызды емес. Бірақ атмосфераның бірлік бағанындағы озонның жалпы көлемін білу керек болып табылады. Атмосферадағы озон стратосферада да, тропосферада да болатын фотохимиялық реакциялардың нәтижесі ретінде қалыптасады.

Сонымен, озон бар үш атмосфералық облыс бар - олар тропосфера, стратосфера және мезосфера. Сәйкесінше, оларды «тропосфералық», «стратосфералық» немесе «мезосфералық озон» деп атайды. Және де бұл атаулар әр қабаттағы озонмен байланысты мәселелердің бір-бірінен айырмашылық жасайтынын көрсетеді.
Өткір мәселелер стратосфералық озонмен байланысты болып келеді. Стратосфералық озон бүкіл Жер шарындағы тірі ағзалардың қорғаушысы іспеттес. Адамзат бүгінде стратосфералық озонның мөлшерінің азайып кетпеуі үшін күресуде.

Жер атмосферасындағы температура мен озон концентрациясының арасындағы байланысқа деген қызығушылық айқын және түсінікті. Стратосфераның негізгі қызуы озон молекулалары күннің ультракүлгін сәулелерін сіңіру нәтижесінде болатыны белгілі. Сондықтан озон концентрациясының өзгеруі осы аймақтың температуралық режимінің өзгеруіне әкеледі. Екінші жағынан, кез келген жылу бұзылуы озонның түзілу және ыдырау реакцияларының жылдамдығына әсер етеді (Kulikov Yu. Yu., Ryskin V. G., 1999: 89).

Брассер мен Соломонның пікірінше, бұл өзара әрекеттесу механизмі температура мен озон құрамы арасында теріс корреляцияға ие (Brasseur, G., and Solomon, S., 1984: 452). Мысалы, Рэнделл планетарлық толқындардың таралуы кезінде жылудың азаюы пайда болады, ол жоғарғы стратосферадағы озон құрамының өзгеруінің қарсы фазасында және төменгі стратосферадағы озон құрамының өзгеруінің фазасында болады. Алайда, озон мен температураның өзара әрекеттесуінің жалпы 
процесінде химиялық, температуралық және динамикалық механизмдердің рөлі жеткіліксіз зерттелген (Randell, W. J., 1993: 3308).

Finger et al ұсынған (Finger, F.G., Nagatani, R.M., 1995: 3477) озон вариацияларының көпжылдық спутниктік өлшеулерін талдау нәтижелері, сонымен қатар төменгі стратосферадағы озон мөлшері мен температура (30 мбар деңгейі) және сәйкесінше 1,0-2,0 мбар арасындағы оң және теріс корреляцияның болуын көрсетеді. Алайда, кері спектрометрмен алынған бұл спутниктік мәліметтерде қысқы жарты шардың полярлық ендіктеріндегі озон мөлшері туралы ақпарат жоқ екенін атап өткен жөн. Сондықтан, стратосферадағы фотохимиялық процестер әлсіреген және динамика шешуші рөл атқара алатын полярлық түн жағдайында озон мен температура арасындағы байланысты зерттеу маңызды болып табылады.

Озонның жалпы құрамының температурамен, қысыммен және атмосферадағы әртүрлі биіктіктегі басқа да метеорологиялық элементтермен байланысын алғаш рет Добсон және оның қызметкерлері 1925-1930 жылдары зерттеді.

Түрлі биіктіктегі озон мен температура арасындағы байланыс сипатын зерттеу үшін көптеген зерттеушілер корреляция коэффициенттерін есептеді. Корреляция коэффициенттері озон мәндері мен бір мезгілде өлшенген температура үшін есептелген. Озон-температура коэффициенттері туралы келесі қорытынды жасауға болады:

1) бір биікке және бір маусымға жататын әртүрлі станциялардың корреляция коэффициенттері шамамен бірдей, бұл зерделенетін байланыстардың кездейсоқ еместігін көрсетеді;

2) 3, 6, 8 және 9 км биіктіктерде корреляция коэффициенттері теріс;

3) 12, 14, 15 және 20 км биіктіктерде корреляция коэффициенттері орташа есеппен оң; бұл ретте жазда және күзде әрдайым оң және көктемде және қыста жиі теріс (биік ендерде);

4) тропосферадан стратосфераға көшкенде орташа корреляция коэффициенттері белгіні керіге ауыстырады;

5) оңтүстік жарты шарда (Мирный станциясы) корреляция коэффициенттерінің белгілері мен шамалары Солтүстік жарты шардағыға ұқсас;

6) корреляция коэффициенттері ендіктен аз тәуелді;

7) корреляция коэффициенттері теңіз деңгейінен биіктікке және жыл уақытына байланысты айтарлықтай өзгереді;

8) тропосферада корреляция коэффициенті орташа $\mathrm{r}=$ минус 0,47 , төменгі стратосфе-

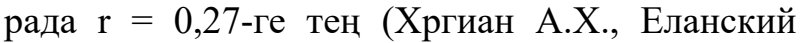
Н.Ф., 1983:156).

Юхансен (Hansen, J., Sato, M., Ruedy, R.,1997: 6831) озон-температура байланысын зерттей отырып, Тромста алынған мәліметтерге сәйкес, ең үлкен теріс корреляция коэффициенті көктемде 6 км биіктікте байқалады деген қорытындыға келді.

Воейков обсерваториясында алынған мәліметтер бойынша “озонның жалпы құрамы мен aуa температурасы арасындағы тығыз байланыс сәуір-мамыр айларында тропосферада 6-9 км биіктікте, ең аз байланыс - күзгі айларда байқалады. 9 км биіктіктегі озон құрамы мен ауа температурасы арасындағы корреляция коэффициенті көктемде $\mathrm{r}=$ минус 0,78 мәніне жетеді. Тропопауза арқылы өткен кезде озон құрамы мен ауа температурасы арасындағы корреляция коэффициенті күрт секіруге ұшырайды. Тропопауза ауданында ол белгісін өзгертеді немесе нөлге жақындап азаяды", - делінген (Хргиан А.Х., Еланский Н.Ф., 1983:156).

Оринг пен Мюнч озонның жалпы құрамының жер бетіндегі температурамен байланысын 100 және 50 мб зерттеді. Зерттеу үшін негізінен Еуропада орналасқан 17 озонометриялық станцияның деректері пайдаланылды. Аэрологиялық деректер озонометриялық станцияларға жақын пункттерден алынды. 1956-1957 жылдардағы озонтемпература корреляция коэффициенттерінің орташа айлық және орташа жылдық мәндері есептелді. Авторлар 100 мб деңгей үшін корреляция коэффициенттері 50 мб деңгей үшін корреляция коэффициенттерінен асып түсетінін атап өтті. Көптеген жағдайларда корреляция коэффициенттері оң болды (Yung Y.L., Jiang Y., Liao H., Gerstell M.F.,1997: 3229-3231).

Мартин мен Бруер бір жағынан, 24 сағаттық кезеңнің соңында озонның жалпы құрамына бөлінген осы пункттегі озонның жалпы құрамының 24 сағаттық өзгерісі, екінші жағынан, 100 мб деңгейіндегі температурадағы 24 сағаттық өзгеріс арасындағы корреляция коэффициентін есептеді. Озонның жалпы құрамы (бір айлық кезеңдегі озонның орташа жалпы құрамына бөлінген) мен 100 мб бетіндегі температура арасындағы корреляция коэффициенті $\mathrm{r}=0,57$ ге тең болды. Бовил мен Хейр Мусони станциясы үшін озонның жалпы мөлшері мен 23,500 км биіктіктегі ауа температурасы арасындағы корреляция коэффициентін есептеді, 1960 жылдың қаңтарында ол $r=0,85$-ке тең болды. Сол уақыт аралығында 200 мб беткейдегі озон-температура корреляция коэффициенті Мусони үшін r 
= 0,42 болды (Martin Dameris, Fabian P., 2014: 356).

Озонның жалпы құрамы мен атмосфера температурасының арасында тығыз байланыс бар және де ол тропосфера үшін теріс, ал стратосфера үшін - оң. Озонның жалпы құрамының ауыткуы негізінен 12-24 км қабаттағы озон құрамының ауытқуымен байланысты, яғни төменгі және орта стратосферада. Демек, озонның тік таралуы атмосферада температураның вертикальды таралуымен байланысты деп қорытынды жасауға болады.

Бұл байланыс озонның тік таралуының ендік тәуелділігімен жақсы көрінеді. 12-24 км қабатта озон мөлшері негізінен ендіктің өсуімен артады. Екінші жағынан, 12-24 км қабаттағы температура ендіктің өсуімен де артады. Осыдан өз кезегінде стратосферадағы ауа температурасы ондағы озонның құрамына байланысты деген қорытынды жасауға болады (Демин В.И., Белоглазов М.И., Еланский Н.Ф., 2004:662-665).

T.C. Селегей (Селегей Т.С., 2007: 46) озонның орташа жылдық құрамы жылдың бірінші жартысындағы атмосфералық ауаның температуралық режимімен байланысты екенін анықтады: бірінші жартыжылдықтағы атмосфералық ауа неғұрлым жылы болса, озон концентрациясының орташа жылдық мәні соғұрлым жоғары болады. Жылудың едәуір адвекциясы кезінде (бірінші жартыжылдықта ауаның орташа айлық температурасы нормадан 5,5-6,0 ${ }^{0} \mathrm{C}$ жоғары) озонның орташа айлық концентрациясы күн сәулесінің болуына қарамастан 40-60 мкг/м ${ }^{3}$ артады. Озонның ең жоғары концентрациясының ең төменгі салыстырмалы ылғалдылыққа тәуелділігі кері сипатта болады: салыстырмалы ылғалдылықтың өсуімен озон концентрациясы төмендейді $(\mathrm{r}=$ -0,37), жекелеген жартыжылдықтарға бөле отырып, байланыс жақсармайды. Төмен салыстырмалы ылғалдылық (30\%-дан аз) озонның жоғары концентрациясының пайда болуы үшін қажетті, бірақ жеткіліксіз шарт болып табылады.

А.В. Холопцев өзінің еңбегінде Украина территориясындағы найзағайдың белсендігі мен озонның жалпы құрамы арасындағы статистикалық байланысты зерттеді. Украинаның барлық дерлік аумағында зерттелген процестер арасындағы байланыс теріс екендігі анықталды (Холопцев А.В., Никифорова М.П., 2011: 57).

Тропопауза мен озонның жалпы құрамының өзара байланысы көптеген зерттеулердің тақырыбы болып табылады (Bethan S., Vaughan G., Reid S.J., 1996: 929-944, Canziani P.O.,
Compagnucci R.H., 2002: 4741, Hoinka K.P., Claude H., 1996: 1753-1756, Hudson R. D., Frolov A. D., 2003: 1669-1677, Steinbrecht W., Claude H., 1998: 19183-19192). Орташа алғанда, тропопаузаның биіктігінің жоғарылауымен атмосфералық полюсте озон мөлшері азаятыны анықталды. Бұл шамалар арасындағы корреляция қалыпты ендік үшін шамамен 0,6 құрайды (Иванова А.Р., 2013: 146-147).

Жер бетіне жеткен күннің ультракүлгін радиациясының қарқындылығы атмосфералық озонның және басқа газ компоненттерінің сіңуіне, сондай-ақ ауа молекулалары мен аэрозольдердің таралуына байланысты екені белгілі. Бұлттылық болмаған кезде оның деңгейі негізінен озонның жалпы құрамымен анықталады (Гущин Г.П., Виноградова Н.Н., 1983: 237).

ОЖҚ және биологиялық белсенді УК-радиацияның тәуліктік және орташа айлық мәндерінің уақыттық қатарларының байланысын талдау нәтижесі $(\lambda \leq 310$ нм $) \quad 50^{\circ}$ с. е.-ден жоғары Солтүстік Американың континентішілік аймағы үшін басқа факторлардың әсеріне қарамастан ОЖҚ жеткілікті жоғары деңгейі негізінен атмосфераның динамикасына байланысты екенін көрсетті, ультракүлгін сәулеленудің өзгеруі ОЖҚ ауытқуларымен модуляцияланады (Зуев В.В., Зуева Н.Е., 2006: 1053-1061). Бұл параметрлер арасында статистикалық тұрғыдан жоғары корреляция деңгейі бар (сенімді ықтималдықпен 0,99-дан жоғары). Сонымен бірге корреляция дәрежесі аймақтың ендік орналасуына, континенталдылығына және оның климаттық жағдайларына байланысты екендігі анықталды.

Озонның басқа ауа қоспаларымен де байланысы зерттелген. Атмосфералық ауаның басқа қоспаларының концентрациясы мен озон концентрациясының өзара тәуелділігін анықтағанда, алынған бірнеше корреляция индекстері қарастырылатын факторлар арасындағы байланыстың орташа дәрежесін көрсетеді $(\mathrm{R}=0,375-0,58)$. Фишер критерийін қолдана отырып регрессиялық арақатынастарды бағалау олардың статистикалық дұрыстығын көрсетті (F=3,06-8,42; $\mathrm{P}<0,05)$. Атмосфералық ауаның озонмен ластану дисперсиясының 14,1\%-дан 33,6\%-ға дейін ауа бассейнінің өзге де газ тәрізді қоспалары бар имплицирленгені анықталды (Голиков Р.А., Суржиков Д.В., 2016: 26-31).

Жер бетіндегі озон мен ауа температурасының байланысы көптеген ресейлік ғалымдармен зерттелді, олар: М.И. Белоглазов, А.А. Ермак, С.А. Румянцев, В. К. Ролдугин, Б. Д. Белан, Т. К. Скляднева және т. б. (Белоглазов М.И., Ермак А.А., 1998: 65). 


\section{Бастапқы деректер мен зерттеу әдістері}

2012-2016 жылдар аралығында Алматы, Атырау, Қарағанды, Арал сияқты станцияларының аэрологиялық мәліметтері АҚШ-тың Вайоминг университетінің сайтынан алынып, өңделіп, озонның жалпы құрамы мен ауа температура- сы, салыстырмалы ылғылдылық және жел жылдамдығы арасындағы байланысы зерттелді. Осы станциялардағы метеоэлементтердің 20 км биіктіктегі мәліметтері алынды және статистикалық зерттеу әдістері қолданылды (http:// weather.uwyo.edu/).

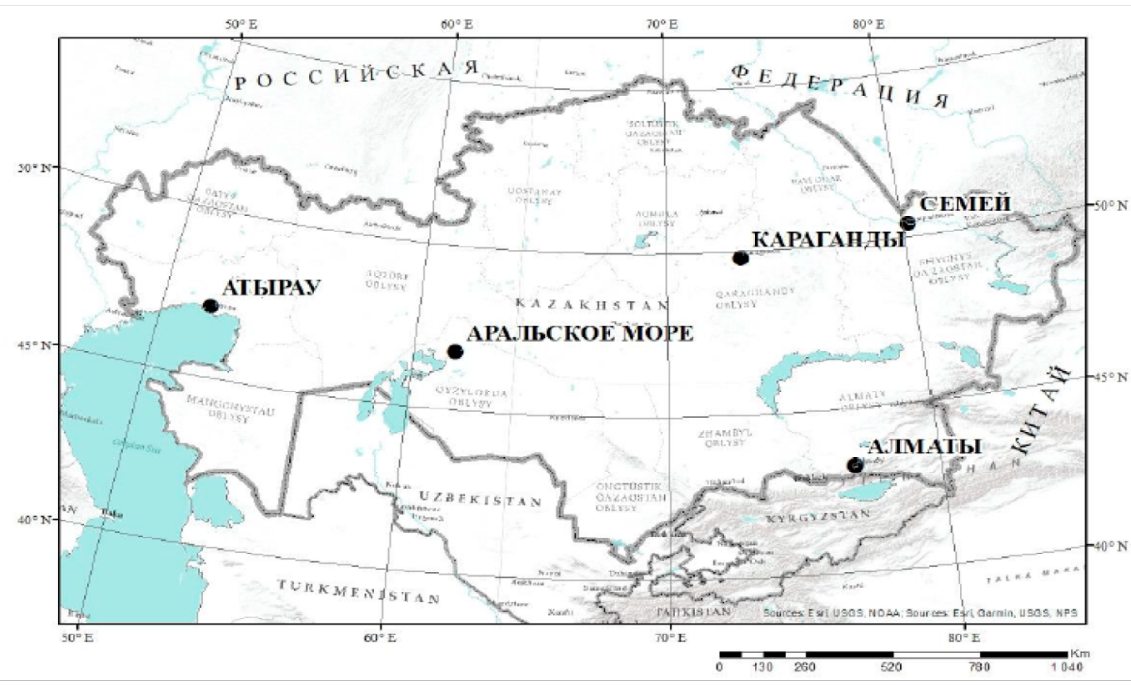

1-сурет - Озонометриялық бақылау станцияларының орналасуы

Озонның максималды концентрациясы 20 -дан 30 км-ге дейін биіктікте байқалатыны белгілі, сондықтан атмосфераның бүкіл бағанасындағы озонның жалпы құрамының өзгеруі стратосфералық концентрацияның негізгі өзгеpicтері деп шартты түрде болжауға болады. Қолданыстағы гипотезаға сәйкес, жер беті озонының қалыптасуының негізгі көзі стратосфералық озон болып табылады және ОЖҚ (озонның жалпы құрамы) мен ЖБО (жер беті озоны) арасында байланыс болуы керек.

\section{Нәтижелері мен талдау}

Сырғымалы 30 күндік орташалауды қолдана отырып (атап айтқанда синоптикалық процестерден туындаған ұсақ периодтарды жою үшін), ОЖҚ мен ЖБО қатарларына кросскорреляциялық талдау жүргізілді.

ОЖҚ мен ЖБО вариацияларын салыстыру кезінде ОЖҚ-ға қатысты ЖБО максимумы мен минимумдарының кешеуілдеуі анықталды, ол 33-тен 52 күнге дейін ауытқып, орташа есеппен 42 күнді құрады (ЖБО және ОЖҚ тәуліктік мәндерінің уақыттық қатарларын 30 күндік орташа есеппен және ОЖҚ-ға қатысты ЖБО кешіктіру кезінде 42 күн ішінде осы қатарлар арасындағы корреляция коэффициенті 0,78 $\pm 0,12$ құрайды). Тәуліктік амплитудасы суық мезгілде (қаңтар) 0,5-1,0 ppb-ден жылы мезгілде (шілде) 5-8 ppb-ге дейін (Potemkin V.L., Potemkina T.G., 2015: 38)

Жыл мезгілдері бойынша озон концентрациясының төмен тәуліктік өзгергіштігі суық мезгілде, жоғары - жылы мезгілде байқалады, бұл әр түрлі беттердегі ағынның температурасы мен мөлшеріне байланысты: қар - 0,02-0,03 см/с, топырақ - 0,1-1,0 см/с), сондай-ақ озонның биотамен өзара әрекеттесуімен, ақаулардың газсыздандырылуымен, найзағай күндерінің көптігімен байланысты (Тимофеева С.С., Латышева И.В., 2008:24-27).

Т. С. Селегей мен Н. Н. Филоненконың еңбектерінде (Селегей Т. С., Филоненко Н. Н., Ленковская Т. Н., 2011: 88) озонның орташа тәуліктік концентрациясы мен күн сәулесінің тәуліктік ұзақтығы арасындағы корреляция коэффициенттері $\mathrm{r}=0,17$ деңгейін көрсететіндігі анықталған. Орташаландыру кезеңінің орташа айлық мәндерге дейін ұлғаюымен корреляция коэффициенті $\mathrm{r}=0,58$-ге дейін, ал орташа

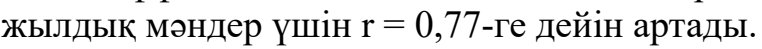




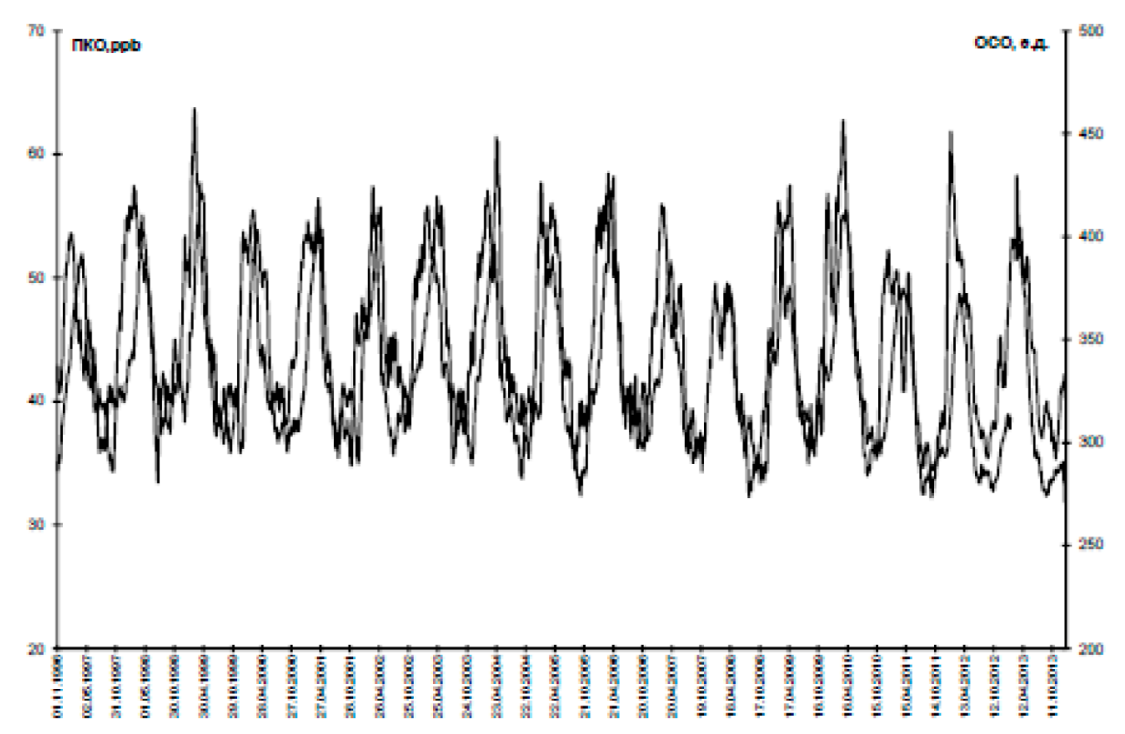

2-сурет - ОСО (нүктелі сызық) және ЖБО (тұтас сызық) көп жылдық өзгерістері

Жердегі озонның ең аз концентрациясы ауаның орташа тәуліктік және максималды температурасымен байланысты $(\mathrm{r}=0,34-0,39)$. Жылы кезеңде (мамыр-қазан) байланыстар күшейеді $(\mathrm{r}=0,48-0,55)$, суықта, керісінше, $\mathrm{r}=$ $0,24-0,25$ дейін төмендейді.

Озон концентрациясының орташа тәуліктік және минималды салыстырмалы ылғалдылыққа тәуелділігі кері және $r=-0,34 \div-0,37$ деңгейінде. Төмен салыстырмалы ылғалдылық (<30 \%) озонның жоғары концентрациясын қалыптастыру үшін қажетті, бірақ жеткіліксіз шарт болып табылады. Жердегі желдің орташа тәуліктік жылдамдығымен және АТ925 мб биіктіктегі желдің жылдамдығымен озонның орташа тәуліктік концентрациясының корреляция коэффициенттері олардың төмен мәндерін көрсетті $(\mathrm{r}=0,01-0,12 ;-0,01 \div-0,09)$. Қыс айларында (қараша-ақпан) тәуелділік 0,27-0,34-ке дейін артады және келесі айларда қайтадан жоғалады. Сонымен қатар, әрбір келесі жыл үшін тәуелділік қисықтары әртүрлі көлбеулі болады.

Озонның максималды концентрациясының желдің бағытына тәуелділігін талдау озонның ең жоғары концентрациясы оңтүстік желдерде, ең төменгісі - шығыс, батыс және солтүстікбатыста пайда болатындығын көрсетті, бұл Батыс Сібірдің оңтүстігінің циркуляциялық ерекшеліктеріне жақсы сәйкес келеді. Оңтүстік желдер жылы және құрғақ ауа массаларын алып жүреді және, әрине, озонның жоғары концентрациясын құрайды. Батыс және солтүстік- батыс желдері белсенді айналым процестерімен байланысты: циклондардың басып кіруі, фронттардың өтуі, жауын-шашын және т. б. Мұндай жағдайларда жердегі озонның жоғары концентрациясы байқалады. Шығыс желдеріне келетін болсақ, олар төмен қайталанушылыққа ие және негізінен орталығы Моңғолияның үстінде орналасқан қысқы күшті антициклондарда байқалады. Мұндай антициклондар суық ауаны Батыс Сібірдің оңтүстігіне озонның төмен концентрациясымен жібереді (Селегей Т. С., Филоненко Н. Н., Ленковская Т. Н., 2011:88).

М. И. Белоглазовтың жұмысында күннің әртүрлі уақыттарындағы жер бетіндегі озон құрамының ауа температурасына корреляциялық тәуелділігінің әр түрлі сипаты анықталды; түстен кейін және кешке корреляция коэффициенті статистикалық маңызды, оң; күннің қалған уақытында статистикалық маңызды емес; жердегі озон құрамының өзгеруі температураның өзгеруінен бірнеше сағатқа артта қалады.

3-суретте аталған станциялардағы озонның жалпы құрамының мәні озон қалыптасатын биіктіктегі ауа температурасы мәнімен байланыс графигі көрсетілген.

3-суреттен көретініміздей, 2014 жылы озон қалыптасатын биіктіктегі ауа температурасы басқа жылдардағы мәндеріне қарағанда әлдеқайда төмен болған, оған ОЖҚ үлкен мәндері сәйкес келеді. Ал стратосферадағы біршама жылынулар 2015 жылы болған, ол өз кезегінде жер бетіндегі циркуляциялық процестер мен ауа рай- 
ына әсерін тигізеді. Және де озон концентрациясы бойынша да Алматы станциясының максимумы да осы жылмен сәйкес екенін көреміз. Сурет бойынша озон концентрациясының аз мәндеріне ауа температурасының жоғары мәндері сәйкес келеді деген қорытынды алуға болады.

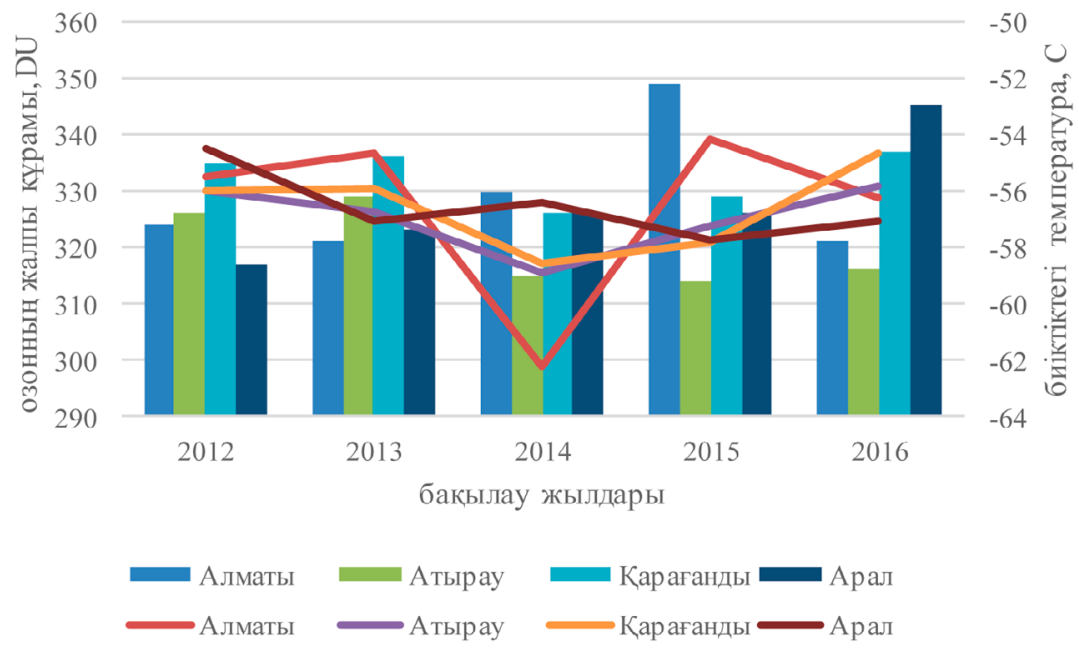

3-сурет - Озонның орташа жылдық жалпы құрамы мен 20 км биіктіктегі ауа температурасы арасындағы байланыс

Жоғарыда айтылғандардан озонға бай стратосфералық массалар көбінесе суық тропосфералық ауа массаларының үстінде, ал озонға кедей стратосфералық массалар жылы тропосфералық массалардың үстінде орналасады деп қорытынды жасауға болады. Төменгі және орта стратосферадағы жылы ауа массалары озонның жоғарылауымен, ал суық ауа массалары төмен мазмұнмен сипатталады (Александров Э.Л., Израэль Ю.А., Кароль И.Л., Хргиан А.Х., 1992: 282).

Озонның жалпы мөлшері мен атмосфераның температурасы арасында тығыз байланыс бар, ол тропосфера үшін теріс, ал стратосфера үшін оң. Озонның жалпы құрамының ауытқуы негізінен 12-24 км қабаттағы озон құрамының, яғни төменгі және орта стратосферадағы ауыткуларына байланысты.

Осыдан озонның вертикальды таралуы атмосферадағы температураның вертикальды таралуымен байланысты деп қорытынды жасауға болады. Бұл байланыс озонның вертикальды таралуының ендік тәуелділігімен жақсы дәлелденді. 12-24 км қабатта озон мөлшері негізінен ендік өскен сайын артады. Екінші жағынан, 12-24 км қабаттағы температура ендік өскен сайын орта есеппен жоғарылайды. Осыдан өз кезегінде стратосферадағы ауа температурасы ондағы озонның құрамына байланысты деп қорытынды жасауға болады (Кадыгрова Т.В., Фиолетов В.Э., 1990: 63).

Озон мөлшерінің өзгеруі стратосфера температурасымен тығыз байланысты. Температураның төмендеуіне белсенді түрде озонды бұзатын заттардың қоспасы бар полярлы стратосфералық бұлттар үнемі пайда болады және полюстерде де, жаһандық масштабта да озон қабатының қалыңдығы күрт төмендейді. Атмосфера күйінің өзгеруі жылдан жылға температураның күрт өзгеруіне әкеледі («Вопросы и ответы об озоновом слое», 2010: 79).

4-суреттен неғұрлым озонның жалпы құрамының мәні жоғары болған сайын, салыстырмалы ылғалдылық мәні соғұрлым төмен болатынын байқаймыз. Оған Алматы және Арал станциялары дәлел бола алады. Озонның жалпы құрамының жоғарғы мәндерінде салыстырмалы ылғалдылық 23 \% (Қарағанды) көрсетсе, оның аз мәнінде Алматы станциясы үшін салыстырмалы ылғалдылық 17 \%-пен тіркелген.

Бақылау орнындағы озонның жалпы құрамы төменгі стратосферадағы желдің бағытына байланысты. Төменгі стратосферадағы солтүстік желдері өлшеу орындарында озонның жалпы мөлшерінің жоғарылауына, оңтүстік - азаюына әкеледі деп болжалды. Мияке мен Кавамура (Monks, P.S. 2000: 3545-3561) сүзгіш озонометрімен озон өлшеулерінің мәліметтеріне сүйене отырып, 
“Жапонияда (Татено) солтүстік желдері кезінде озонның жалпы мөлшері артатынын анықтады.
Озон мен желдің бағыты арасындағы корреляция коэффициенттері ендікке аз тәуелді болып келеді.

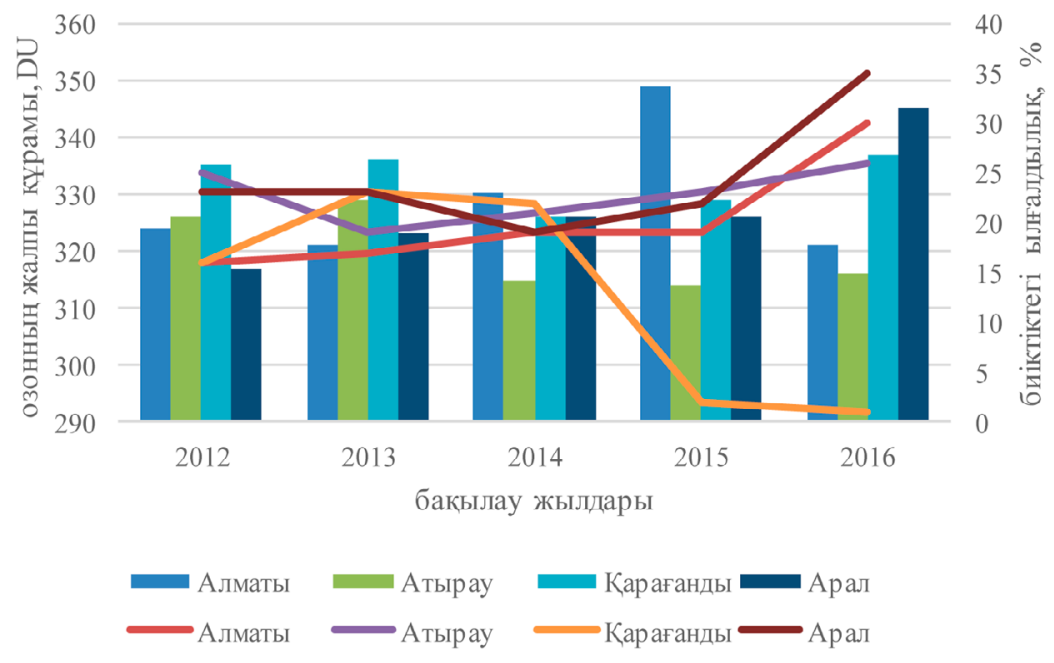

4-сурет - Озонның орташа жылдық жалпы құрамы мен 20 км биіктіктегі салыстырмалы ылғалдылық арасындағы байланыс

К.И. Ромашкинаның жұмысында (Ромашкина К.И., Шаламянский А.М., 1980: 72) Алматы үшін 9 және 15 км биіктіктегі озонның жалпы құрамы мен желдің меридионалды және аймақтық құраушылары арасындағы байланыс зерттелді. 1961 жылғы озон туралы мәліметтер пайдаланылды, озонның жалпы құрамы мен жыл мезгілдері бойынша желдің құрамдас бөліктері арасындағы корреляция коэффициенттері есептелді. Желдің меридионалды және аймақтық құраушылары солтүстік-оңтүстік және батыс- шығыс осьтеріндегі вектордың проекциясы ретінде анықталды. Озон мен желдің корреляция коэффициенттері Алматыда аз және өзгермелі. Корреляция коэффициентінің белгісі биіктікке де, жыл мезгіліне де белгілі бір заңдылықсыз өзгереді. Бұл Алматыда 9 және 15 км биіктіктерде озонның жалпы құрамы мен желдің меридионалдық және аймақтық құраушыларының арасында елеулі байланыс жоқ екенін білдіреді, алайда басқа жерлерде қарастырылатын байланыс неғұрлым тығыз болуы мүмкін екенін ескеру керек.

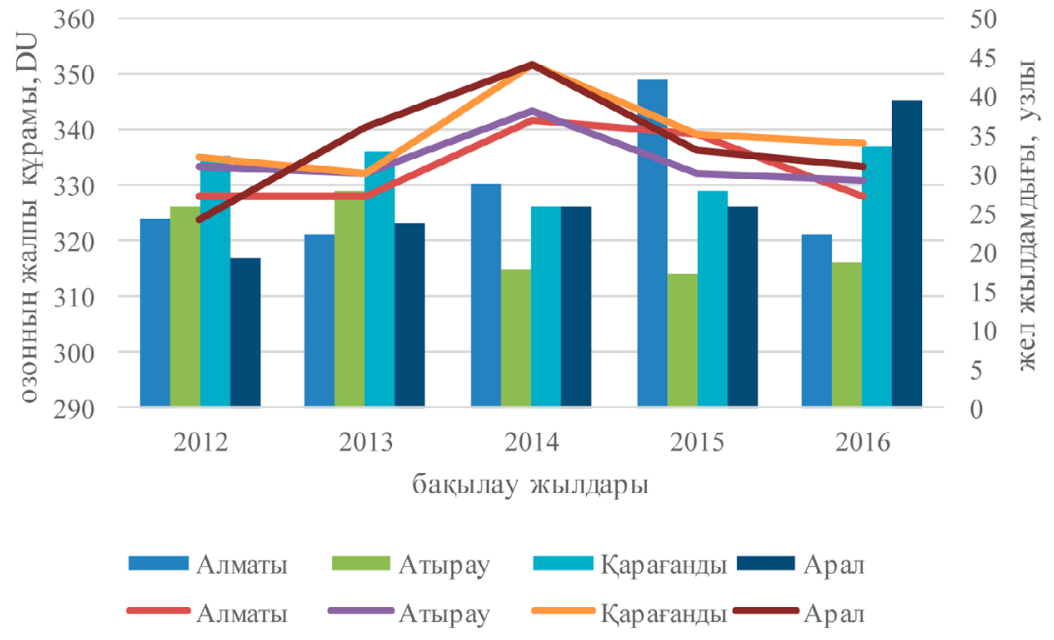

5-сурет - Озонның орташа жылдық жалпы құрамы мен 20 км биіктіктегі жел жылдамдығы арасындағы байланыс 
Қарастырылып отырған жылдар аралығында 2014 жылы 20 км-ден жоғары биіктікте желдің жылдамдығы басқа жылдармен салыстырғанда жоғары болғанын көреміз. Ол циркуляциялық ерекшеліктердің әсерінен болуы әбден ықтимал.

Метеорологияда көбінесе корреляциялық талдау бір үлгідегі көптеген параметрлер арасындағы байланысты зерттеуді қамтиды. Яғни корреляциялық есептеулер қарастырылатын көптеген параметрлердің жұбының әрқайсысы үшін жасалады (Солтаганов Н.А., Ботыгин И.А., 2017: 199-200). Бұл жұмыста өзара байланыс (корреляциялық байланыс) келесі метеорологиялық параметрлер арасында зерттеледі: озонның жалпы құрамы, температура, салыстырмалы ылғалдылық.

1-кесте - Озонның жалпы құрамы мен метеошамалар арасындағы корреляциялық байланыс

\begin{tabular}{|c|c|c|c|c|c|}
\hline Таңдаулы шамалар & 2012 жыл & 2013 жыл & 2014 жыл & 2015 жыл & 2016 жыл \\
\hline ауа температурасы және ОЖҚ & $-0,9$ & $-0,2$ & $-0,3$ & 0,8 & $-0,2$ \\
\hline $\begin{array}{c}\text { салыстырмалы ылғалдылық және } \\
\text { ОЖҚ }\end{array}$ & $-0,2$ & 0,5 & $-0,3$ & $-0,1$ & $-0,1$ \\
\hline жел жылдамдығы және ОЖҚ & 0,9 & $-0,08$ & 0,3 & 0,8 & 0,6 \\
\hline
\end{tabular}

«-» белгісі метеошамалардың үлкен мәндері озонның жалпы құрамының аз мәндеріне сәйкес келетінін көрсетеді, ол дегеніміз бұл мәндер арасындағы теріс корреляция ұғымын береді.

«+» белгісі метеошамалардың аз мәндері озонның жалпы құрамының аз мәндеріне сәйкес келетінін көрсетеді, ол дегеніміз бұл мәндер арасындағы оң корреляция ұғымын береді.

Жоғарыда айтылғандарды ескере келе, 2013 жылы салыстырмалы ылғалдылық пен озонның жалпы құрамы арасындағы, 2015 жылы температура пен озонның жалпы құрамы арасындағы оң корреляциялық байланысты көреміз. Жел жылдамдығы мен озонның жалпы құрамы арасындағы байланыс та оң корреляцияны көрсетеді. Басқа жағдайларда теріс корреляциялық байланыс байқалған.

\section{Қорытынды}

Тік ауа бағанындағы озонның (ОЖҚ) жалпы мөлшері атмосфералық озонның негізгі сипаттамасы болып табылады. Жердің жасанды серіктерінеорнатылғанозонныңжалпы құрамына өлшеу жабдықтарын белсенді қолданудың басталуымен обсерватория жағдайындағыдай жергілікті өлшеу ғана емес, сонымен қатар жер шарының бүкіл бетін жаһандық жабу мүмкіндігі пайда болды. Озонның жалпы құрамы туралы мәліметтер жүйелі түрде жарияланады, барлық ғалымдарға қол жетімді және әдебиеттерде егжей-тегжейлі қарастырылған.

Қорытындылай келе, келесідей тұжырымдамалар алынды:

- әр метеорологиялық фактор озон концентрациясының қалыптасуына ықпал етеді, әсіресе, озонның вертикальды таралуы атмосферадағы температураның вертикальды таралуымен тығыз байланысты;

- озонға бай стратосфералық массалар көбінесе суық тропосфералық ауа массаларының үстінде, ал озонға кедей стратосфералық массалар жылы тропосфералық массалардың үстінде орналасады;

- стратосфераның қатты қызуы әсерінен ауа температурасы мен ОЖҚ арасындағы оң байланыс анықталды, ал ол қалыпты жағдайда теріс байланысқа ие;

- неғұрлым озонның жалпы құрамының мәні жоғары болған сайын, салыстырмалы ылғалдылық мәні соғұрлым төмен болады;

- озон мен желдің бағыты арасындағы корреляция коэффициенттері көбінесе оң және ендікке аз тәуелді. Ары қарайғы зерттеулер статистикалық талдаудың көпөлшемді әдістерін (факторлық, кластерлік, бірнеше регрессиялық талдау) пайдалануды көздейді. 


\section{Әдебиеттер}

Вопросы и ответы об озоновом слое // Озоновый центр, программа ООН по окружающей среде, 2010. - 79 с.

Bethan S., Vaughan G., Reid S.J. A comparison of ozone and thermal tropopause heights and the impact of tropopause definition on quantifying the ozone content of the troposphere // Quarterly J. Royal Meteorol. Society. - 1996. - Vol. 122. - P. 929-944.

Brasseur, G., and S. Solomon, Aeronomy of the Middle Atmosphere, 452 pp., D. Reidel, Norwell, Mass., 1984.

Canziani P.O., Compagnucci R.H., Bischoff S.A., Legnani W.E. A study of impacts of tropospheric synoptic processes on the genesis and evolution of extreme total ozone anomalies over Southern South America // J. Geophys. Res. - 2002. - Vol. 107. - P. $4741-4766$.

Finger, F. G., R. M. Nagatani, M. E. Gelman, C. S. Long, and A. J. Miller, Consistency between variations of ozone and temperature in the stratosphere, Geophys. Res. Lett., 22 (24), 3477, 1995.

Hansen, J., Sato, M., Ruedy, R. (1997) Radiative forcing and climate response. J. Geophys. Res. Atmos., 102, 6831-6864. doi:10.1029/96JD03436.

Hoinka K. P., Claude H., Köhler U. On the correlation between tropopause pressure and ozone above Central Europe // Geophys. Res. Let. - 1996. - Vol. 23 (14). - P. 1753-1756.

Hudson R. D., Frolov A. D., Andrade M. F., Follette M.B. The total ozone field separated into meteorological regimes. Part I: defining the regimes // J. Atm. Sci. - 2003. - Vol. 60. - P. 1669-1677.

Martin Dameris, P.Fabian. Ozone in the atmosphere. Berlin, 2014, p 356.

Monks, P.S. A review of the observations and origins of the spring ozone maximum. // Atmos. Environment. V. 34. - P. 35453561,2000

Randell, W. J., Global variations of zonal mean ozone during stratospheric warming events, J. Atmos. Sci., 50 (19), $3308,1993$.

Steinbrecht W., Claude H., Köhler U., Hoinka K. P. Correlations between tropopause height and total ozone: Implications for long-term changes // J. Geophys. Res. - 1998. - Vol. 103. - P. 19183-19192.

Potemkin V.L., Potemkina T.G., Guseva E.A. Atmospheric ozone dynamics in highland, Вестник ИрГТУ, №3 (98) 2015, p. 38

Yu. Yu. Kulikov and V. G. Ryskin., Relation between ozone and temperature in the Arctic stratosphere. Institute of Applied Physics, Nizhny Novgorod, Russia., International Journal of Geomagnetism and Aeronomy, Vol 1, No. 3, August 1999, p. 89

Yung Y.L., Jiang Y., Liao H., Gerstell M.F., Enhanced UV penetration due to ozone cross-section changes induced by C02 doubling, Geophysical Research letters, vol.24, no24, p.3229-3231, December 15, 1997

Холопцев А.В., Никифорова М.П. Особенности статистической связи межгодовых изменений среднемесячных значений общего содержания озона и индексов грозовой активности над Украиной / Севастопольский национальный технический университет // Вісник Одеського державного екологічного університету, 2011, вип.12. - С. 57.

Иванова А.Р. Взаимосвязь динамики внетропической тропопаузы и резких междусуточных изменений общего содержания озона в период 2009-2011 гг. // Труды Гидрометеорологического научно-исследовательского центра Российской Федерации, 2013, n 347. - С. 146-147.

Александров Э.Л., Израэль Ю.А., Кароль И.Л., Хргиан А.Х. Озонный щит Земли и его изменения. - СПб.: Гидрометеоиздат. 1992. - 282 с.

Белоглазов М.И., Ермак А.А., Румянцев С.А., Ролдугин В.К. Некоторые результаты измерений содержания приземного озона на побережье Белого моря // Метеорология и гидрология. - 1998. - №10. - 65 с.

Вайоминг университетінің ресми сайты http://weather.uwyo.edu/

Голиков Р.А., Суржиков Д.В., Олещенко А.М., Кислицына В.В., Корсакова Т.Г., Мотуз И.Ю. Взаимосвязь между концентрациями озона и концентрациями компонентов промышленных выбросов в атмосферном воздухе // Научноисследовательский институт комплексных проблем гигиены и профессиональных заболеваний, 2016. - С. 26-31.

Гущин Г.П., Виноградова Н.Н. Суммарный озон в атмосфере. - Л.: Гидрометеоиздат, 1983. - 237 с.

Зуев В.В., Зуева Н.Е. Влияние вариаций суммарного озона на изменение уровня солнечной УФ-В радиации // Оптика атмосферы и океана, 2006. Т.19. - №12: 1053-1061.

Кадыгрова Т. В., Фиолетов В. Э. Банк данных «Озонометрия» и статистическое описание поля общего содержания озона. Атмосферный озон. - М.: Гидрометеоиздат, 1990. - С. 63.

Солтаганов Н. А., Ботыгин И.А Корреляционный анализ метеорологических данных / Томский политехнический университет // XV Международная научно-практическая конференция студентов аспирантов и молодых учёных «Молодёжь и современные информационные технологии», 2017. - С. 199-200.

Демин В.И., Белоглазов М.И., Еланский Н.Ф. О связи приземной концентрации озона и высоты слоя перемешивания // Оптика атмосферы и океана. Том 17. - 2004. - № 8. - С. 662-665.

Ромашкина К.И., Шаламянский А.М. Некоторые вопросы методики измерения содержания озона на сети озонометрических станций //Труды ГГО. Вып. 445. - 1980. - С. 72.

Селегей Т. С., Филоненко Н. Н., Ленковская Т. Н. Изменчивость содержания приземного озона в атмосферном воздухе Новосибирска и его зависимость от метеорологических факторов // Академическое издательство «Гео», 2011. - С. 88.

Селегей Т.С. Влияние метеорологических факторов на формирование концентраций приземного озона в г. Новосибирске // Труды СибНИГМИ, 2007, вып. 15. - С. 46.

Тимофеева С.С., Латышева И.В., Потемкин В.Л. Динамика грозовой активности и ее влияние на вариации озона в регионе оз. Байкал // Вестник ИрГТУ. - 2008. - № 2 (34). - С. 24-27.

Хргиан А.Х., Еланский Н.Ф. Атмосферный озон. - М.: Изд. МГУ, 1983. - 156 с. 


\section{References}

«Voprosy i otvety ob ozonovom sloe» (2010) // Ozonovyj centr, programma OON po okruzhajushhej srede, [Questions and answers about the ozone layer],79 s.

Bethan S., Vaughan G., Reid S.J. (1996) A comparison of ozone and thermal tropopause heights and the impact of tropopause definition on quantifying the ozone content of the troposphere // Quarterly J. Royal Meteorol. Society. - Vol. 122. - P. 929-944.

Brasseur, G., and S. Solomon. (1984) Aeronomy of the Middle Atmosphere, 452 pp., D. Reidel, Norwell, Mass.

Canziani P.O., Compagnucci R.H., Bischoff S.A., Legnani W.E. (2002) A study of impacts of tropospheric synoptic processes on the genesis and evolution of extreme total ozone anomalies over Southern South America // J. Geophys. Res. - Vol. 107. - P. $4741-4766$.

Finger, F. G., R. M. Nagatani, M. E. Gelman, C. S. Long, and A. J. Miller. (1995) Consistency between variations of ozone and temperature in the stratosphere, Geophys. Res. Lett., 22 (24), 3477.

Hansen, J., Sato, M., Ruedy, R. (1997) Radiative forcing and climate response. J. Geophys. Res. Atmos., 102, 6831-6864. doi:10.1029/96JD03436.

Hoinka K. P., Claude H., Köhler U. (1996) On the correlation between tropopause pressure and ozone above Central Europe // Geophys. Res. Let. - Vol. 23 (14). - P. 1753-1756.

Hudson R. D., Frolov A. D., Andrade M. F., Follette M.B. (2003) The total ozone field separated into meteorological regimes. Part I: defining the regimes // J. Atm. Sci. - Vol. 60. - P. 1669-1677.

Martin Dameris, P. Fabian. (2014) Ozone in the atmosphere. Berlin, p. 356.

Monks, P.S. (2000) A review of the observations and origins of the spring ozone maximum. // Atmos. Environment. V. 34, P.3545-3561.

Randell, W. J. (1993) Global variations of zonal mean ozone during stratospheric warming events, J. Atmos. Sci., 50 (19), 3308.

Steinbrecht W., Claude H., Köhler U., Hoinka K. P. (1998) Correlations between tropopause height and total ozone: Implications for long-term changes // J. Geophys. Res. - Vol. 103. - P. 19183-19192.

Potemkin V.L., Potemkina T.G., Guseva E.A. (2015) Atmospheric ozone dynamics in highland, Vestnik IrGTU, №3 (98), r. 38

Yu. Yu. Kulikov and V. G. Ryskin. (1999) Relation between ozone and temperature in the Arctic stratosphere. Institute of Applied Physics, Nizhny Novgorod, Russia., International Journal of Geomagnetism and Aeronomy, Vol 1, No. 3, August r. 89

Yung Y.L., Jiang Y., Liao H., Gerstell M.F. (1997) Enhanced UV penetration due to ozone cross-section changes induced by C02 doubling, Geophysical Research letters, vol.24, no24, p.3229-3231, December 15.

Holopcev A.V., Nikiforova M.P. (2011) Sevastopol'skij nacional'nyj tehnicheskij universitet, Osobennosti statisticheskoj svjazi mezhgodovyh izmenenij srednemesjachnyh znachenij obshhego soderzhanija ozona i indeksov grozovoj aktivnosti nad Ukrainoj // Visnik Odes'kogo derzhavnogo ekologichnogo universitetu , [Features of statistical relationship between annual changes in monthly average values of total ozone and thunderstorm activity indices over Ukraine], vip.12, str 57.

Ivanova A.R. (2013) Vzaimosvjaz' dinamiki vnetropicheskoj tropopauzy i rezkih mezhdusutochnyh izmenenij obshhego soderzhanija ozona v period 2009-2011 gg. // Trudy Gidrometeorologicheskogo nauchno-issledovatel'skogo centra Rossijskoj Federacii, [Relationship between the dynamics of the extratropical tropopause and sharp inter-day changes in the total ozone content in the period 2009-2011], n 347, 146-147 str

Aleksandrov Je.L., Izrajel' Ju.A., Karol’ I.L., Hrgian A.H. (1992) Ozonnyj shhit Zemli i ego izmenenija [Earth's ozone shield and its changes] $\mathrm{SPb} .:$ Gidrometeoizdat. $-282 \mathrm{~s}$.

Beloglazov M.I., Ermak A.A., Rumjancev S.A., Roldugin V.K. (1998) Nekotorye rezul'taty izmerenij soderzhanija prizemnogo ozona na poberezh'e Belogo morja. // Meteorologija i gidrologija. [Some results of measurements of ground-level ozone on the White sea coast] - №10. $-65 \mathrm{~s}$.

Vajoming universitetiniң resmi sajty http://weather.uwyo.edu/ [Official website of the University of Wyoming]

Golikov R.A., Surzhikov D.V., Oleshhenko A.M., Kislicyna V.V., Korsakova T.G., Motuz I.Ju. (2016) Vzaimosvjaz' mezhdu koncentracijami ozona i koncentracijami komponentov promyshlennyh vybrosov v atmosfernom vozduhe // Nauchno-issledovatel'skij institut kompleksnyh problem gigieny i professional'nyh zabolevanij, [Relationship between ozone concentrations and concentrations of industrial emissions components in atmospheric air], 26-31 str

Gushhin G.P., Vinogradova N.N. (1983) Summarnyj ozon v atmosfere, [Total ozone in the atmosphere] L., Gidrometeoizdat, 237 s.

Zuev V.V., Zueva N.E. (2006) Vlijanie variacij summarnogo ozona na izmenenie urovnja solnechnoj UF-V radiacii [Influence of variations in total ozone on changes in the level of solar UV-B radiation] // Optika atmosfery i okeana, T.19. №12: $1053-1061$.

Kadygrova T. V., Fioletov V. Je. (1990) Bank dannyh "Ozonometrija" i statisticheskoe opisanie polja obshhego soderzhanija ozona [Ozonometry data Bank and statistical description of the total ozone content field] Atmosfernyj ozon. - M., Gidrometeoizdat, str 63

Soltaganov N. A., Botygin I. A. (2017) Korreljacionnyj analiz meteorologicheskih dannyh [Correlation analysis of meteorological data] // Tomskij politehnicheskij universitet XV Mezhdunarodnaja nauchno-prakticheskaja konferencija studentov aspirantov i molodyh uchjonyh «Molodjozh' i sovremennye informacionnye tehnologii», 199-200 str

Demin V.I., Beloglazov M.I., Elanskij N.F. (2004) O svjazi prizemnoj koncentracii ozona i vysoty sloja peremeshivanija [On the relationship between the ground-level ozone concentration and the mixing layer height] //Optika atmosfery $\mathrm{i}$ okeana, tom $17, \mathrm{~N}$ 8, str.662-665.

Romashkina K.I., Shalamjanskij A.M. (1980) Nekotorye voprosy metodiki izmerenija soderzhanija ozona na seti ozonometricheskih stancij [Some questions of the method of measuring the ozone content on the network of ozonometric stations] //Trudy GGO. Vyp. 445, str 72 . 
Selegej T. S., Filonenko N. N., Lenkovskaja T. N. (2011) Izmenchivost' soderzhanija prizemnogo ozona v atmosfernom vozduhe Novosibirska i ego zavisimost' ot meteorologicheskih faktorov [Variability of ground-level ozone content in the atmospheric air of Novosibirsk and its dependence on meteorological factors] // Akademicheskoe izdatel'stvo «Geo», str 88

Selegej T.S. (2007) Vlijanie meteorologicheskih faktorov na formirovanie koncentracij prizemnogo ozona v g. Novosibirske [Influence of meteorological factors on the formation of ground-level ozone concentrations in Novosibirsk]// Trudy SibNIGMI, vyp. $15, \operatorname{str} 46$

Timofeeva S.S., Latysheva I.V., Potemkin V.L. (2008) Dinamika grozovoj aktivnosti i ee vlijanie na variacii ozona v regione oz. Bajkal [Dynamics of thunderstorm activity and its influence on ozone variations in the oz region. Baikal] // Vestnik IrGTU. № 2 (34). s. $24-27$.

Hrgian A.H., Elanskij N.F. (1983) Atmosfernyj ozon. [Atmospheric ozone]. - M.: Izd. MGU. - 156 s. 